\title{
Regulation of Nucleus Accumbens Activity by the Hypothalamic Neuropeptide Melanin-Concentrating Hormone
}

\author{
Robert M. Sears, ${ }^{1,2}$ Rong-Jian Liu, ${ }^{1}$ Nandakumar S. Narayanan, ${ }^{3,4}$ Ruth Sharf, ${ }^{1}$ Mark F. Yeckel,,${ }^{2,5}$ Mark Laubach, $, 3,5$ \\ George K. Aghajanian, ${ }^{1}$ and Ralph J. DiLeone ${ }^{1,2,5}$ \\ ${ }^{1}$ Department of Psychiatry, Ribicoff Research Facilities, Yale University School of Medicine, New Haven, Connecticut 06508, ${ }^{2}$ Interdepartmental \\ Neuroscience Program, Yale University, New Haven, Connecticut 06520, ${ }^{3}$ The John B. Pierce Laboratory, New Haven, Connecticut 06519, ${ }^{4}$ Department of \\ Neurology, Yale University School of Medicine, New Haven, Connecticut 06520, and 5epartment of Neurobiology, Yale University School of Medicine, New \\ Haven, Connecticut 06520
}

The lateral hypothalamus and the nucleus accumbens shell (AcbSh) are brain regions important for food intake. The AcbSh contains high levels of receptor for melanin-concentrating hormone (MCH), a lateral hypothalamic peptide critical for feeding and metabolism. MCH receptor (MCHR1) activation in the AcbSh increases food intake, while AcbSh MCHR1 blockade reduces feeding. Here biochemical and cellular mechanisms of $\mathrm{MCH}$ action in the rodent AcbSh are described. A reduction of phosphorylation of GluR1 at serine 845 (pSer ${ }^{845}$ ) is shown to occur after both pharmacological and genetic manipulations of MCHR1 activity. These changes depend upon signaling through $\mathrm{G}_{\mathrm{i} / \mathrm{o}}$, and result in decreased surface expression of GluR1-containing AMPA receptors (AMPARs). Electrophysiological analysis of medium spiny neurons (MSNs) in the AcbSh revealed decreased amplitude of AMPAR-mediated synaptic events (mEPSCs) with MCH treatment. In addition, MCH suppressed action potential firing MSNs through $\mathrm{K}^{+}$channel activation. Finally, in vivo recordings confirmed that $\mathrm{MCH}$ reduces neuronal cell firing in the AcbSh in freely moving animals. The ability of $\mathrm{MCH}$ to reduce cell firing in the AcbSh is consistent with a general model from other pharmacological and electrophysiological studies whereby reduced AcbSh neuronal firing leads to food intake. The current work integrates the hypothalamus into this model, providing biochemical and cellular mechanisms whereby metabolic and limbic signals converge to regulate food intake.

\section{Introduction}

While individual brain nuclei are involved in feeding behavior, how these nuclei integrate to regulate food intake is not clear. Both the lateral hypothalamus (LH) and the nucleus accumbens shell (AcbSh) are well established for their role in feeding, and evidence suggests a cross talk between these regions is important for food intake (Kelley, 2004; Georgescu et al., 2005). Both regions express a number of neuropeptides and neuropeptide receptors that could mediate hypothalamic-AcbSh communication, but their specific roles, and cellular mechanisms of action require further investigation.

Melanin-concentrating hormone $(\mathrm{MCH})$ is a 19 amino acid cyclic peptide produced in the lateral regions of the hypothala-

\footnotetext{
Received Nov. 18, 2009; revised April 23, 2010; accepted May 1, 2010.

This work was supported by DK073677 (R.J.D.), a National Alliance for Research on Schizophrenia and Depression Young Investigator Award (R.J.D.), and the State of Connecticut, Department of Mental Health and Addiction Services (R.J.D.). We thank Dr. Eleftheria Maratos-Flier for the knock-out and overexpressing MCH mice lines. We thank Dr. Maysa Sarhan for help with figure design. We thank Dr. Erika Andrade, Dr. Fan-Yan Wei, and Dr. Douglas Guarnieri for experimental suggestions and reagents. The DARPP-32 antibodies were provided by Dr. Angus Nairn The antibody against MCH was provided by Dr. Wylie Vale.

Correspondence should be addressed to Ralph J. DiLeone, Division of Molecular Psychiatry, Department of Psychiatry, Yale University School of Medicine, Connecticut Mental Health Center, 34 Park Street, New Haven, CT 06508. E-mail: ralph.dileone@yale.edu.

DOI:10.1523/JNEUROSCI.5858-09.2010

Copyright $\odot 2010$ the authors $\quad 0270-6474 / 10 / 308263-11 \$ 15.00 / 0$
}

mus and is a key regulator of food intake and metabolism (Skofitsch et al., 1985; Vaughan et al., 1989; Bittencourt et al., 1992). Both pharmacological and genetic studies suggest a key role for MCH in food intake (Qu et al., 1996; Rossi et al., 1997; Shimada et al., 1998; Ludwig et al., 2001; Della-Zuana et al., 2002; Gomori et al., 2003; Ito et al., 2003; Shearman et al., 2003; Mashiko et al., 2005). Consistent with a physiological role in fasting responses, $\mathrm{MCH}$ mRNA is upregulated by fasting or leptin deficiency, which can be reversed by leptin treatment (Kokkotou et al., 2001).

$\mathrm{MCH}$-expressing axons and MCHR1 are found in many brain nuclei, but they are notably concentrated in limbic regions important for motivated behaviors (Skofitsch et al., 1985; Bittencourt et al., 1992; Hervieu et al., 2000). Specifically, MCHR1 is highly expressed in medium spiny neurons (MSNs) of the AcbSh, a subdivision of the nucleus accumbens (Saito et al., 2001; Georgescu et al., 2005). The nucleus accumbens is implicated in mediating the reinforcing properties of food, sex, and drugs of abuse (Robbins and Everitt, 1996; Cardinal et al., 2002; Kelley and Berridge, 2002) and plays an important role in mood regulation (Berton and Nestler, 2006). We have previously shown that $\mathrm{MCH}$ delivery to the AcbSh, but not the nucleus accumbens core, increases food intake and MCHR1 antagonist in the AcbSh reduces feeding (Georgescu et al., 2005).

The orexigenic (pro-feeding) effects of intra-AcbSh MCH resemble the feeding response following AcbSh infusions of either 
an AMPA receptor antagonist (Maldonado-Irizarry et al., 1995; Stratford et al., 1998) or GABA receptor agonists (Stratford and Kelley, 1997, 1999; Reynolds and Berridge, 2001), suggesting that an overall reduction in AcbSh neuronal activity can drive feeding. In support of this idea, analysis of neuronal firing in the AcbSh during operant behaviors for palatable substances reveals reduced action potential firing in a majority of neurons (Taha and Fields, 2006).

The present experiments aim to better define the biochemical and cellular consequences of $\mathrm{MCH}$ action in the AcbSh. Since reduced neuronal excitability in the AcbSh occurs with feeding and other appetitive behaviors and $\mathrm{MCH}$ drives feeding in this structure, it was hypothesized that the feeding peptide $\mathrm{MCH}$ acts to reduce neuronal excitability in the AcbSh. The following data provide biochemical and cellular mechanisms for how hypothalamic-limbic integration controls the drive to feed.

\section{Materials and Methods}

Animals. The described procedures were in adherence to protocols approved by the Institutional Animal Care and Use Committee of Yale University or the John B. Pierce Laboratory. Experiments were performed using male Sprague Dawley rats from Charles River Laboratories, or with MCH knock-out (KO) (Shimada et al., 1998) and MCHoverexpressing (OE) (Ludwig et al., 2001) mouse lines. In vivo recordings were conducted in male Long-Evans rats from Harlan. Weights and ages are specified in each section.

Slice preparations for biochemistry. Sprague Dawley rats, 3.5-5 weeks of age (90-140 g) were rapidly decapitated and brains removed. Brains were transferred to a $20 \%$ sucrose slurry (in oxygenated $\left(95 \% \mathrm{O}_{2} / 5 \% \mathrm{CO}_{2}\right.$ ) artificial CSF (aCSF): $\mathrm{NaCl} 124 \mathrm{~mm}, \mathrm{KCl} 4 \mathrm{~mm}, \mathrm{NaHCO}_{3} 26 \mathrm{~mm}$, D-glucose $10 \mathrm{~mm}, \mathrm{CaCl}_{2} 1.5 \mathrm{~mm}, \mathrm{MgSO}_{4} 1.5 \mathrm{~mm}$, and $\mathrm{KH}_{2} \mathrm{PO}_{4} 1.25 \mathrm{~mm}$, $\mathrm{pH}$ 7.5) and allowed to harden for $30 \mathrm{~s}$ to $1 \mathrm{~min}$. Brains were coronally blocked at the level of the hypothalamus and superglued to a vibratome stage (Vibratome). Brains were cut in ice-cold, oxygenated sucrose-aCSF into $350 \mu \mathrm{m}$ slices. AcbSh was rapidly dissected in ice-cold, oxygenated aCSF and transferred to room temperature aCSF. Slices were slowly equilibrated to $30^{\circ} \mathrm{C}$ for $1 \mathrm{~h}$ and transferred to $5 \mathrm{ml}$ round-bottom tubes with fresh $30^{\circ} \mathrm{C}$ aCSF plus vehicle (water), $10 \mu \mathrm{M} \mathrm{MCH}$ (Anaspec), $50 \mu \mathrm{M}$ MCHR1 antagonist (PMC-3881-PI, Peptides International), or $10 \mu \mathrm{M}$ $\mathrm{MCH}$ and $50 \mu \mathrm{M}$ MCHR1 antagonist. We have used this antagonist (Bednarek et al., 2002) in previous behavioral and biochemical studies (Georgescu et al., 2005). With the exception of time course experiments, $\mathrm{MCH}$ treatments lasted for $30 \mathrm{~min}$. For phospholipase C (PLC) inhibitor experiments, slices were preincubated for $15 \mathrm{~min}$ in U73122 (15 $\mu \mathrm{M})$ (Tocris Bioscience) or aCSF containing vehicle (DMSO) followed by 30 min with DMSO, U73122, or U73122 combined with $\mathrm{MCH}$ in fresh $30^{\circ} \mathrm{C}$ aCSF. For D1R agonist treatments, aCSF was replaced with fresh $30^{\circ} \mathrm{C}$ aCSF containing $10 \mu \mathrm{M}$ of the D1R agonist SKF 81297 (Sigma) or vehicle for $5 \mathrm{~min}$.

Western blotting procedure and antibodies. Immediately before sonication of slices, $50 \mu \mathrm{l}$ of boiling $1 \%$ SDS [2\% SDS for bis(sulfosuccinimidyl) suberate $\left(\mathrm{BS}^{3}\right)$ cross-linking studies] including protease and phosphatase inhibitor cocktails 1 and 2 was added to each tube (Sigma). Following sonication, lysate was boiled for $10 \mathrm{~min}$, with the exception of $\mathrm{BS}^{3}$-treated tissue. Protein was quantified using a Bio-Rad Laboratories $\mathrm{DC}$ assay, and $15 \mu \mathrm{g}$ of protein $\left(20 \mu \mathrm{g}\right.$ for BS ${ }^{3}, \mathrm{MCH}-\mathrm{KO}$, and MCH-OE experiments) was loaded on an Invitrogen Bis-Tris Midi or Mini gel $(4-12 \%)$ following the provided instructions. For MCH-KO and $\mathrm{MCH}-\mathrm{OE}$ experiments, Western blots were performed using the Bio-Rad Laboratories Protean II XL apparatus and $8 \%$ Tris- $\mathrm{HCl}$ gels. $\mathrm{BS}^{3}$ samples were run using $4-12 \%$ precast gels or poured $7.5 \%$ Tris- $\mathrm{HCl}$ gels.

For GluR1 protein detection, membranes were first blotted with the phospho-antibodies at 1:500 (rabbit polyclonal, GluR1 Ser ${ }^{845}$ and Ser ${ }^{831}$ antibodies from PhosphoSolutions). Afterward, membranes were stripped and blotted with a total GluR1 antibody (rabbit polyclonal, 1:1000, Abcam). GluR2 antibody was used at 1:1000 (rabbit polyclonal, Abcam). Dopamine- and cAMP-regulated phosphoprotein of $32 \mathrm{kDa}$
(DARPP-32) antibodies were a generous gift from Dr. Angus Nairn, Yale University, New Haven, CT. Rabbit $\alpha$-threonine $34\left(\right.$ Thr $\left.^{34}\right)$ (1:1000) and mouse $\alpha$-DARPP-32 $(1: 10,000)$ were coincubated. For detection of cAMP response element-binding protein (CREB), mouse $\alpha$-serine 133 $\left(\operatorname{Ser}^{133}\right)$ antibody (1:1000, Millipore) was coincubated with rabbit $\alpha$-CREB antibody (1:500, Cell Signaling Technology). Mitogen-activated protein kinase (MAPK or ERK2) levels were detected by coincubation with a rabbit $\alpha$-tyrosine 202/204 (Tyr ${ }^{202 / 204}$ ) (Cell Signaling Technologies) antibody and a mouse $\alpha$-pan-MAPK antibody (1:5000, BD Biosciences). Following overnight incubation at $4^{\circ} \mathrm{C}$, blots were incubated in Alexa-conjugated secondary antibodies for $1 \mathrm{~h}$ at $4^{\circ} \mathrm{C}(1: 5000$, Invitrogen and/or Rockland Immunochemicals). Blots were scanned and quantified using a LiCor Odyssey scanner and fluorescent images were converted to grayscale for publication.

Cannulations for in vivo pharmacology and biochemistry. Sprague Dawley rats ( $\sim 9$ weeks, $300-350 \mathrm{~g}$ ) were anesthetized and cannulated with double-barreled cannulae aimed at the AcbSh using coordinates and procedures previously described (Georgescu et al., 2005). After 1 week of recovery, animals were handled for $5 \mathrm{~d}$, and then infused (two animals at a time, one for each treatment) with drug or vehicle ( $1 \mu \mathrm{g}$ for both $\mathrm{MCH}$ and MCHR1 antagonist, dissolved in aCSF composed of $\mathrm{NaCl} 147 \mathrm{~mm}$, $\mathrm{CaCl}_{2} 1.3 \mathrm{~mm}, \mathrm{MgCl}_{2} 0.9 \mathrm{~mm}, \mathrm{KCl} 4.0 \mathrm{~mm}$ ). Thirty minutes following infusion, animals were decapitated and brains were rapidly removed, frozen on dry ice, and stored at $-80^{\circ} \mathrm{C}$. Frozen brains were cut on a cryostat at $250 \mu \mathrm{m}$ and the AcbSh was microdissected (while frozen) for tissue processing and Western blotting. Given the occasional asymmetry of injection sites, each side was considered an individual treatment. Tissue was kept at $-80^{\circ} \mathrm{C}$ until processing.

In vivo pertussis toxin injections. Sprague Dawley rats between 3.5 and 5 weeks of age $(90-130 \mathrm{~g})$ were anesthetized with pentobarbital $(5 \mathrm{mg} /$ $\mathrm{kg}$ ) and mounted on a stereotaxic apparatus. Coordinates are as follows: $10^{\circ}$ angle, $+1.4 \mathrm{~cm} \mathrm{AP},+2.0 \mathrm{ML},-6.3 \mathrm{DV}$. One side was infused with 1.5 $\mu \mathrm{g}$ of pertussis toxin (PTX, in $0.5 \mu \mathrm{l}$ of $1 \times$ PBS) and the other with $1 \times$ PBS vehicle. Animals were allowed to recover in their home cage for $16-24 \mathrm{~h}$ before the experiment. Brains were treated as described above in Slice preparations for biochemistry.

$B S^{3}$ cross-linking procedure. $\mathrm{BS}^{3}$ (Thermo Fisher Scientific) is a membrane-impermeable cross-linking agent. Cross-linked proteins run at a higher molecular weight on an SDS-PAGE gel, thus allowing the distinction between surface and intracellular protein populations. AcbSh slices were prepared from Sprague Dawley rats between 4 and 5 weeks old ( $\sim 120-140 \mathrm{~g})$. After incubation with $\mathrm{MCH}$ or vehicle, $2-3$ slices per animal were combined and treated as previously described (Boudreau and Wolf, 2005) with $\mathrm{BS}^{3}$, although the tissue was cross-linked for 45 min instead of $30 \mathrm{~min}$. After sonication, tissue was briefly centrifuged, aliquoted, and frozen at $-80^{\circ} \mathrm{C}$ until quantitation and Western blotting. The ratio of surface to internal GluR1 signal is reported here.

Slice preparation for electrophysiology. Rats 3.5-5 weeks old were anesthetized with chloral hydrate (400 mg/kg, i.p.). Following decapitation, the brains were removed rapidly and placed in aCSF in which sucrose (252 mM) was substituted for $\mathrm{NaCl}$ (sucrose-aCSF) to prevent cell swelling. A block of tissue containing nucleus accumbens was isolated and coronal slices $(300 \mu \mathrm{m})$ were cut in sucrose-aCSF with an oscillatingblade tissue slicer (VT1000S, Leica Microsystems). A slice containing the AcbSh was transferred to the stage of a submerged recording chamber and secured by a fine mesh attached to a platinum wire frame and perfused with oxygenated, standard aCSF at room temperature. After placement of the slice, the bath temperature was raised to $32^{\circ} \mathrm{C}$. Known concentrations of drugs dissolved in aCSF, applied through a stopcock arrangement at a fast flow rate $(\sim 4 \mathrm{ml} / \mathrm{min})$, reached the slice within $7-10 \mathrm{~s}$. The standard aCSF ( $\mathrm{pH} \sim 7.35$ ) was equilibrated with $95 \% \mathrm{O}_{2} / 5 \%$ $\mathrm{CO}_{2}$ and contained the following: $\mathrm{NaCl}, 128 \mathrm{~mm}$ KCl, $3 \mathrm{~mm} ; \mathrm{CaCl}_{2}, 2$ $\mathrm{mm} ; \mathrm{MgSO}_{4}, 2 \mathrm{~mm} ; \mathrm{NaHCO}_{3}, 24 \mathrm{~mm} ; \mathrm{NaH}_{2} \mathrm{PO}_{4}, 1.25 \mathrm{~mm}$, D-glucose, 10 $\mathrm{mm}$. A recovery period of $1-2 \mathrm{~h}$ was allowed before recording.

Slice electrophysiology. MSNs were visualized using an Olympus BX50WI $(40 \times$ or $60 \times$ IR lens) with infrared differential interference contrast (IR/DIC) video microscopy (Olympus). Low-resistance patch pipettes (3-5 M $\Omega$ ) were pulled from patch-clamp glass tubing (Warner Instruments) using a Flaming-Brown Horizontal Puller (Model P-97, 
A

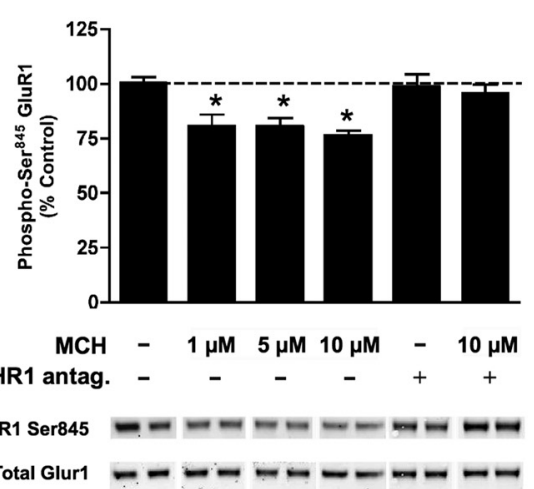

C

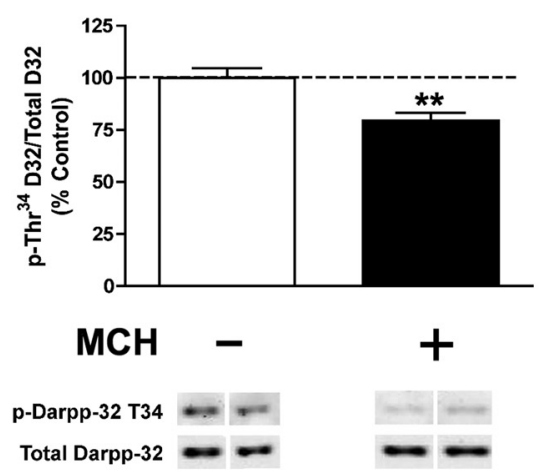

E

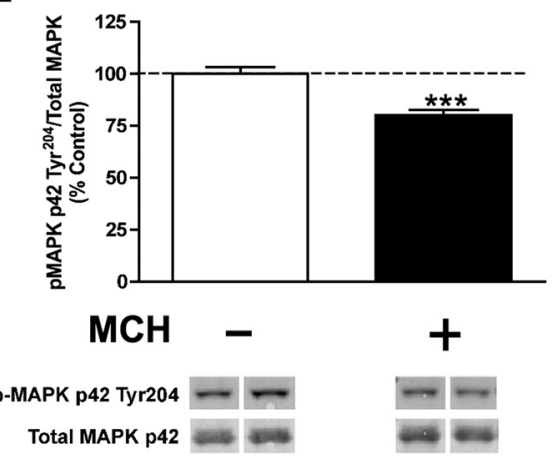

Figure 1. MCH reduces GluR1 pSer ${ }^{845}$ and phosphorylation of other PKA targets. Graphs represent the ratio of phosphorylated signal to total protein signal for all treatments. Below the graphs are treatment conditions and representative Western blot bands for GluR1 pSer ${ }^{845}$ and total GluR1. Data are shown in comparison to vehicle-treated tissue as $100 \%$ (dotted line). $A$, MCH reduced GluR1 pSer ${ }^{845}$ ( $n=6-44$ slices per group for both sets). $\boldsymbol{B}$, The PKC/CaMKIl phosphorylation site on GluR1, pSer ${ }^{831}$, is not affected by MCH treatment ( $n=20$ slices per group). C $-\boldsymbol{E}$, Phosphorylated DARPP-32 $\operatorname{Thr}^{34}(n=18$ per group) (C), phosphorylated CREB $S^{133}\left(n=8-10\right.$ slices) (D), and phosphorylated MAPK Tyr ${ }^{204}(n=13-16$ slices per group) (E) are reduced by MCH in the AcbSh. ${ }^{*} p<0.05,{ }^{* *} p<0.01,{ }^{* * *} p<0.001$. Error bars indicate + SEM.

Sutter Instruments). The pipettes were filled with the following solution: $115 \mathrm{~mm}$ K gluconate, $5 \mathrm{~mm} \mathrm{KCl}, 2 \mathrm{~mm} \mathrm{MgCl}$, 2 mm Mg-ATP, $2 \mathrm{~mm}$ $\mathrm{Na}_{2}$ ATP, $10 \mathrm{~mm} \mathrm{Na}$-phosphocreatine, $0.4 \mathrm{~mm} \mathrm{Na}_{2} \mathrm{GTP}, 10 \mathrm{~mm}$ HEPES, $\mathrm{pH}$ 7.33. For cell labeling experiments, pipettes were tip-filled with the above solution and backfilled with Neurobiotin-containing solution (0.3\%, Vector Laboratories).

Whole-cell recordings were performed with an Axoclamp-2B amplifier (Molecular Devices). The output signal was low-pass filtered at 3 $\mathrm{kHz}$, amplified $100 \times$ though Cyberamp, digitized at $15 \mathrm{kHz}$, and acquired using pClamp 9.2/Digidata 1320 software (Molecular Devices). Series resistance, monitored throughout the experiment, was normally between 4 and $8 \mathrm{M} \Omega$. To minimize series resistance errors, cells were discarded if series resistance rose above $10 \mathrm{M} \Omega$. Postsynaptic currents were studied in the continuous single-electrode voltage-clamp mode; cells were usually clamped near their resting potential to minimize hold- ing currents. Ramp experiments were also performed as previously described (Liu et al., 2005), but were held at a potential of $-65 \mathrm{mV}$ with ramping to $-125 \mathrm{mV}$. For currentevoked spike firing experiments, under these conditions the reversal potential for $\mathrm{K}^{+}$was approximately $-90 \mathrm{mV}$.

In vivo electrophysiology. Two well habituated Long-Evans rats (aged 3-4 months, $\sim 350$ g) were implanted with cannulae (Plastics One) and arrays of microwire electrodes (NB Labs) using aseptic stereotaxic methods described in detail previously (Narayanan et al., 2006). The arrays consisted of eight Tefloncoated, $50 \mu \mathrm{m}$ stainless steel wires arranged in a $3 \times 3 \times 2$ configuration, with each electrode spaced by $\sim 200 \mu \mathrm{m}$. The in vitro impedance of the electrodes was $100-300 \mathrm{k} \Omega$. Anesthesia was initiated with $\sim 4 \%$ halothane and intraperitoneal injections of ketamine $(100 \mathrm{mg} / \mathrm{kg})$ and diazepam $(10 \mathrm{mg} / \mathrm{kg})$. A surgical level of anesthesia was maintained over the course of surgery with supplements (30 $\mathrm{mg} / \mathrm{kg}$ ) of ketamine every $45-60 \mathrm{~min}$. The skull was leveled between bregma and lambda and a single craniotomy was performed over the ventral striatum. A single array of microwire electrodes was placed at AP: +1.6, ML: \pm 0.7 , DV: -7.2 (coordinates from bregma). A single infusion cannula was then placed at AP: $+1.6, \mathrm{ML}: \pm 4.0, \mathrm{DV}:-8.0$ (coordinates from bregma and using an angle of $25^{\circ}$ in the frontal plane). Craniotomies were sealed with cyanoacrylate ("SloZap," Pacer Technologies) accelerated by "ZipKicker" (Pacer Technologies), and methyl methacrylate (i.e., dental cement; AM Systems).

After a recovery period of $7 \mathrm{~d}$, animals were acclimated to recording procedures (i.e., headsets and cables were attached to the implants) for $1 \mathrm{~d}$. Then, drug infusions were performed according to methods described in detail previously (Narayanan et al., 2006). Animals were lightly anesthetized with halothane via a nosecone for $1 \mathrm{~min}$, and recording headstages were plugged in. After initial recording, data acquisition was paused, animals were held and infused with either aCSF $\left(\mathrm{NaCl} 147 \mathrm{~mm}, \mathrm{CaCl}_{2}\right.$ $\left.1.3 \mathrm{~mm}, \mathrm{MgCl}_{2} 0.9 \mathrm{~mm}, \mathrm{KCl} 4.0 \mathrm{~mm}\right), \mathrm{MCH}(1$ $\mu \mathrm{g})$, or fluorophore-conjugated muscimol (FCM) (Narayanan et al., 2006; Allen et al., 2008) (Invitrogen) at a concentration of 0.1 $\mathrm{mg} / \mathrm{ml}$. Infusions were made with 33 gauge cannula (Plastics One) that protruded $0.2 \mathrm{~mm}$ from the tip of the guide cannulae. Injectors were inserted into the guide cannulae and $0.5 \mu \mathrm{l}$ of infusion fluid was delivered per site at a rate of $0.25 \mu \mathrm{l} / \mathrm{min}$ via a syringe infusion pump (KDS Scientific). Fluid was infused via $0.38-\mathrm{mm}$-diameter polyethylene tubing (Intramedic) that connected the injector to a $10 \mu \mathrm{l}$ Hamilton syringe (Hamilton). Injections were confirmed by monitoring movement of fluid in the tubing via a small air bubble. After injection was complete, the injector was left in place for 2 min to allow for diffusion.

Infusions took place between 4:00 and 5:00 P.M. Recording data were collected for $1 \mathrm{~h}$ after infusions. Immediately before and after infusions, animals were allowed to freely move in a Plexiglas cage housed in a custom-made Faraday cage while neural data were collected.

Neural ensemble recordings were made using a Many Neuron Acquisition Program (Plexon). Putative single neural units were identified on-line using an oscilloscope and an audio monitor. The Plexon off-line 
sorter was used to analyze the signals off-line and to remove artifacts due to cable noise and behavioral devices (pump, click stimulus). Principal component analysis (PCA) and waveform shape were used for spike sorting. Single units were identified as having (1) consistent waveform shape, (2) separable clusters in PCA space, (3) average amplitude estimated at least three times larger than background activity, and (4) a consistent refractory period of at least $2 \mathrm{~ms}$ in interspike interval histograms. Those units identified on-line as potential single units that did not meet these criteria off-line were not included in this analysis. Graphical exploratory analysis of neural activity and quantitative analysis of basic firing properties (firing rate, interspike intervals, burst rate, surprise entropy) were performed using Stranger (Biographics). Datasets were previewed using NeuroExplorer (NexTechnologies) and subsequently analyzed using custom routines for MATLAB.

To investigate the effects of $\mathrm{MCH}$ on neural activity, the following experimental design was used. Fifteen minutes of spontaneous neural activity was collected from seven well isolated neurons in two freely moving animals with cannulae and microwire electrodes in the AcbSh. Then, rats (who were well handled) were lightly held while aCSF was infused, and $60 \mathrm{~min}$ of further neural data were collected. In separate recording sessions on separate days, spontaneous data were collected from six well isolated neurons in the same two animals. Then rats were lightly held while $\mathrm{MCH}$ was infused into the ventral striatum, and $60 \mathrm{~min}$ of further spontaneous data were collected. Finally, in a third record session on a separate day, spontaneous data were collected from six well isolated neurons in the same two animals. Then rats were lightly held while fluorescent muscimol was infused into the ventral striatum, and $60 \mathrm{~min}$ of further spontaneous data were collected (supplemental Fig. S4, available at www.jneurosci. org as supplemental material).

For each well isolated neuron, postinfusion firing rates were normalized to mean preinfusion firing rates (in the 5 min immediately preceding drug infusion) and binned (60 s bins). Activity was then compared between neurons recorded in $\mathrm{MCH}$ and aCSF conditions.

Immunohistochemistry and histology. $\mathrm{MCH}$ immunostaining was performed as previously described (Georgescu et al., 2005). Rabbit polyclonal anti-MCH antibody was used at 1:2000 (antibody courtesy of W. Vale, Salk Institute, La Jolla, CA). For cell filling and imaging experiments, slices were fixed overnight in $4 \%$ PFA (in $1 \times$ PBS) at $4^{\circ} \mathrm{C}$. Using a floating protocol, slices were rinsed three times in $1 \times$ PBS for 15 min followed by $1 \mathrm{~h}$ of blocking in $0.3 \%$ Triton X-100 in $1 \times$ PBS $+3 \%$ normal goat serum at room temperature. Slices were coincubated with anti-MCH antibody or serum (for no primary antibody control) overnight at $4^{\circ} \mathrm{C}$ with gentle agitation. Following primary antibody incubation, slices were rinsed three times for $15 \mathrm{~min}$ at room temperature and incubated in $1 \times$ PBS plus Streptavidin conjugated to Alexa-594 (1:1500; Invitrogen) and goat anti-rabbit Alexa 488 (1:200) for $4 \mathrm{~h}$ at room temperature. After three 15 min rinses in $1 \times$ PBS, slices were mounted and coverslipped using Vectashield Fluorescent Mounting Medium (Vector Laboratories) for twophoton microscope imaging.

A

C

B

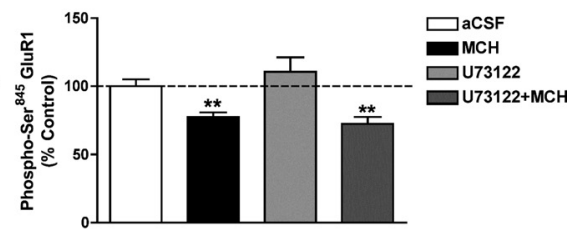

Figure 2. $M C H$ acts via $\mathrm{G}_{\mathrm{i} / 0}$ to reduce $\mathrm{GluR} 1 \mathrm{pSer}{ }^{845}$ in the AcbSh. Graphs represent the ratio of phosphorylated signal to total protein signal for all treatments. $\boldsymbol{A}$, Basal or SKF 81297 -mediated GluR1 pSer ${ }^{845}$ reduction by MCH is blocked by in vivo PTX treatment ( $n=12-15$ slices per group). $\boldsymbol{B}$, MCH-mediated reduction is not affected by inhibition of PLC-PKC pathway with

Figure 3. MCH modulates GluR1 $\mathrm{pSer}^{845}$ in vivo. $A, B$, Infusion of $\mathrm{MCH}$ into the AcbSh of intact animals reduced GluR1 $\mathrm{pSer}{ }^{845}$ group) show reduced ( $\boldsymbol{C}$ and MCH-KO ( $n=8$ per group) show elevated (D) basal GluR1 $\mathrm{pSer}^{845}$ in the AcbSh. ${ }^{*} p<0.05,{ }^{* *} p<$ 0.01. Error bars indicate +SEM.

For placement analysis for in vivo recordings, animals were killed for histology $40 \mathrm{~min}$ following infusions of FCM. Rats were anesthetized with $100 \mathrm{mg} / \mathrm{kg}$ sodium pentobarbital and then transcardially perfused with either $10 \%$ formalin or $4 \%$ paraformaldehyde. Brains were horizontally sectioned on a freezing microtome, mounted on frosted slides using Vectashield Fluorescent Mounting Medium. Electrode locations were visualized and translated to their placement in a coronal slice.

Statistical analyses. All biochemical data represent the ratio of phosphorylated protein signal to total protein signal and statistics were run following normalization to a defined control (aCSF, WT, SKF). ANOVA tests were calculated using SPSS, while Student's $t$ tests were calculated using GraphPad Prism (GraphPad Software). Time course, dose-response, and $\mathrm{BS}^{3}$ slice experiments were analyzed using one-way ANOVA with a Dunnett's post hoc test where appropriate. Multiple ANOVA tests were used for comparing treatment variables of the following: (1) aCSF, $\mathrm{MCH}$, and MCHR1 antagonist for both $30 \mathrm{~min} \mathrm{BS}^{3}$ - and non- $\mathrm{BS}^{3}$ treated slices, (2) in vivo infusions of aCSF, $\mathrm{MCH}$, and MCHR1 antagonist, (3) aCSF, MCH, and U73122 treatment, (4) aCSF, PTX, MCH, and SKF, and (5) electrophysiology data for current-evoked action potential 
A
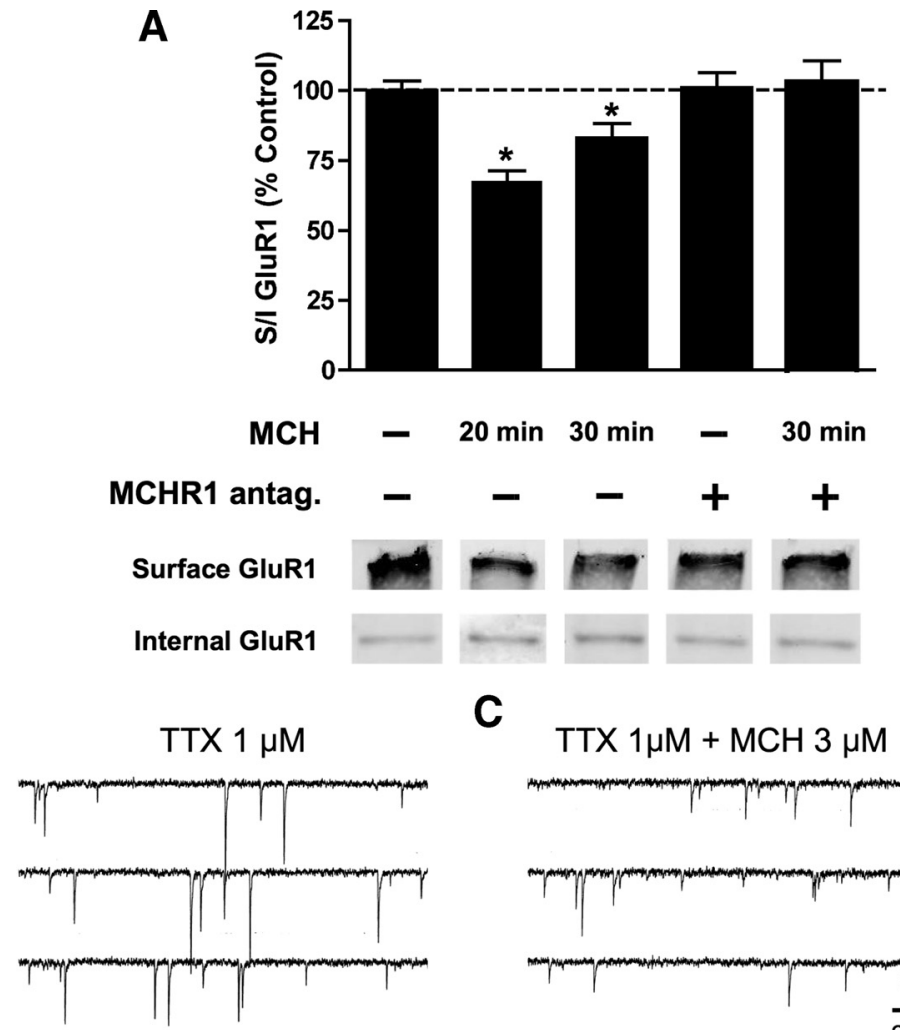

B

D

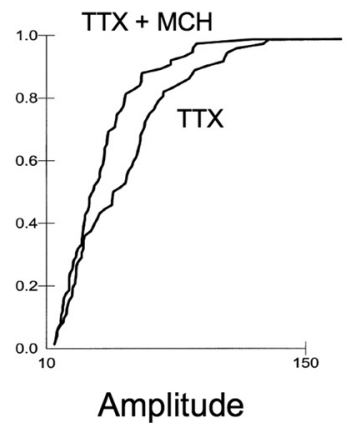

$20 \mathrm{~min} 30 \mathrm{~min} \quad-\quad 30 \mathrm{~min}$

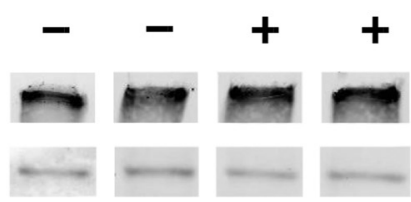

C
$\mathbf{E}$

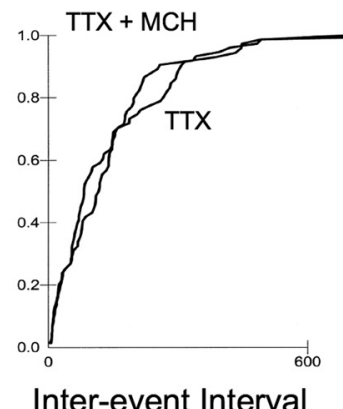

Inter-event Interval

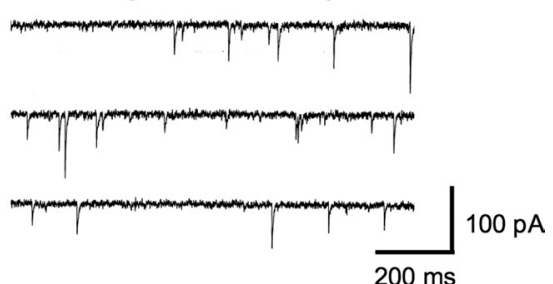

Figure 4. Surface levels of GluR1 and mEPSC amplitude are reduced by MCH in MSNs of the AcbSh. $A$, Data represent the ratio of surface (cross-linked) to internal (un-cross-linked) GluR1 signal, and is normalized to untreated control. Treatment conditions are indicated below the graph along with representative surface and internal GluR1 signal ( $n=7-10$ slices per group). $B, C$, Representative traces before $(\boldsymbol{B})$ and after $(\boldsymbol{C})$ bath application of $\mathrm{MCH}(3 \mu \mathrm{M}) . \boldsymbol{D}, \boldsymbol{E}$, Cumulative probability histogram for amplitude (D) and interevent interval $(\boldsymbol{E}) . n=8$ neurons for mEPSC recordings; ${ }^{*} p<0.05 .,{ }^{* *} p<0.01$. Error bars indicate + SEM.

firing and input resistance. All multiple ANOVA tests were followed by Tukey post hoc tests, with the exception of electrophysiology data, which used a Bonferroni post hoc test. An unpaired, two-tailed Student's $t$ test was used to compare (1) phosphorylated GluR1 signal in WT animals versus $\mathrm{MCH}-\mathrm{KO}$ or MCH-OE and (2) the effects of MCH treatment on GluR1 (Ser ${ }^{831}$ ), DARPP-32, CREB, and MAPK phosphorylation. A Kolmogorov-Smirnov test was use to compare synaptic events for each cell before and after $\mathrm{MCH}$ treatment. A paired two-tailed $t$ test was used to compare grouped data of mEPSC amplitude and frequency before and after $\mathrm{MCH}$, and firing frequency for in vivo electrophysiology recordings.

\section{Results}

MCHR 1 couples to $G_{i / o}$ to reduce cAMP-dependent kinase (PKA)-mediated phosphorylation in AcbSh

MCHR1 is a G-protein-coupled receptor (GPCR) that has been shown to couple to both $\mathrm{G}_{\mathrm{i} / \mathrm{o}}$ and $\mathrm{G}_{\mathrm{q}}$ in different cell systems (Bächner et al., 1999; Hawes et al., 2000; Gao and van den Pol, 2001; Pissios et al., 2003). $\mathrm{G}_{\mathrm{i} / \mathrm{o}}$ signaling is known to oppose the downstream effects of $\mathrm{G}_{\mathrm{s}}$-mediated activity and reduce the activation of PKA. Consistent with reduced PKA activity, a reduction in phosphorylation was seen on multiple PKA substrates, including a basal reduction in GluR1 phosphorylation at serine 845 (henceforth referred to as GluR1 pSer ${ }^{845}$ ). While we have previously reported a reduction in dopamine D1 receptor (D1R)-mediated GluR1 pSer ${ }^{845}$ by $\mathrm{MCH}$ (Georgescu et al., 2005), we found $\mathrm{MCH}$ treatment alone is sufficient to reduce GluR1 pSer ${ }^{845}$ (Fig. $\left.1 A\right)\left(F_{(3,144)}=\right.$ 13.316, $p<0.0001)$ in a time-dependent fashion (supplemental Fig. S1 $B$, available at www.jneurosci.org as supplemental material) $\left(F_{(4,113)}=10.632, p<0.01\right)$, with no effect on total GluR1 protein levels (see supplemental Fig. S2A, available at www.jneurosci.org as supplemental material). To confirm specificity, slices were coincubated with $\mathrm{MCH}$ and an MCHR1 peptide antagonist which blocked the effects of MCH on Ser ${ }^{845}$ phosphorylation (Fig. 1A). The observed changes are specific to the PKA site, since phosphorylation at GluR1 Ser ${ }^{831}$, a protein kinase $\mathrm{C}(\mathrm{PKC}) /$ calcium/calmodulin-dependent protein kinase II (CaMKII) target, was unaffected (Fig. $1 B$ ). In addition, DARPP-32 phosphorylation at the $\mathrm{Thr}^{34}$ PKA site was reduced after $\mathrm{MCH}$ treatment (Fig. 1C) $\left(t_{(1,35)}=3.457, p<0.01\right)$. Finally, phosphorylation was also reduced on PKAdependent sites of CREB at $\operatorname{Ser}^{133}$ (Fig. 1D) $\left(t_{(1,34)}=3.496, p<0.01\right)$ and phosphoMAPK at $\operatorname{Tyr}^{204}$ (Fig. 1E) $\left(t_{(1,34)}=4.825\right.$, $p<0.0001)$.

To determine the role of $\mathrm{G}_{\mathrm{i} / \mathrm{o}}$ activity on MCHR1 signaling, rats were unilaterally infused with the $\mathrm{G}_{\mathrm{i} / \mathrm{o}}$ inhibitor PTX $(1.5 \mu \mathrm{g} / 0.5 \mu \mathrm{l})$ or vehicle (PBS) on alternate sides of the AcbSh. One day after surgery, brains were removed and slices prepared for pharmacological treatment. At the dose used, PTX alone produced no significant change in GluR1 pSer ${ }^{845}$ levels, while D1R agonist SKF 81297 caused increases on both sides (Fig. $2 A)\left(F_{(1,100)}=173.94, p<0.0001\right)$. Although MCH caused reductions in both basal and D1R-mediated phosphorylation on the control side $\left(F_{(1,100)}=13.673, p<0.0001\right)$, this effect was blocked by treatment of PTX $\left(F_{(1,100)}=3.927, p<0.05\right)$. These data indicate that the effect of MCH on GluR1 Ser ${ }^{845}$ in the AcbSh is mediated by a PTX-sensitive $\mathrm{G}_{\mathrm{i} / \mathrm{o}}$ mechanism.

Studies in cell culture systems suggest that MCHR1 activation can lead to $\mathrm{G}_{\mathrm{q}}$-coupled effects (Hawes et al., 2000; Pissios et al., 2003). $\mathrm{G}_{\mathrm{q}}$ mediates the activation of PLC, an upstream activator of $\mathrm{PKC}$. To assess a requirement of PKC signaling on phospho-GluR1 $\mathrm{Ser}^{845}$, AcbSh slices were incubated with the PLC inhibitor U73122 $(15 \mu \mathrm{M})$ for $15 \mathrm{~min}$ followed by coincubation with $\mathrm{MCH}$. Inhibition of PLC failed to attenuate or alter the MCH-mediated reduction in GluR1 pSer ${ }^{845}$ (Fig. $\left.2 B\right)\left(F_{(1,16)}=21.131, p<0.0001\right)$, suggesting that this occurs independent of PLC or PKC activity. 
A previous study in striatal slices demonstrated that the phosphatase calcineurin (PP2B) specifically dephosphorylates GluR1 $\mathrm{Ser}^{845}$, and requires an influx of extracellular calcium (Snyder et al., 2003). Consistent with these data, incubation of AcbSh slices with the calcium chelator EGTA caused a significant increase in phosphorylation at GluR1 $\operatorname{Ser}^{845}\left(F_{(1,20)}=\right.$ 9.331, $p<0.006$ ) (supplemental Fig. S3, available at www.jneurosci.org as supplemental material). However, $\mathrm{MCH}$ reduced Ser ${ }^{845}$ phosphorylation by the same magnitude $\left(F_{(1,20)}=12.12, p<0.002\right)$, indicating that $\mathrm{a} \mathrm{Ca}^{2+}-\mathrm{PP} 2 \mathrm{~B}$ pathway is not activated by $\mathrm{MCH}$. These data support a $\mathrm{G}_{\mathrm{i} / \mathrm{o}^{-}}$, but not $\mathrm{G}_{\mathrm{q}^{-}}$or calcium-dependent mechanism for MCHR1-mediated reduction of phospho-GluR1 Ser ${ }^{845}$ in the AcbSh.

\section{Effects of MCH in vivo on AMPAR subunit GluR1 phosphorylation in the AcbSh}

To confirm the signaling changes in the intact brain, we infused MCH or MCHR1 antagonist directly into the AcbSh of cannulated rats. Consistent with our observation in AcbSh brain slices, $\mathrm{MCH}$ infusion significantly reduced basal GluR1 pSer ${ }^{845}$ compared to vehicle- (artificial CSF, aCSF) and antagonist-treated rats (Fig. $3 A)\left(F_{(2,33)}=10.036, p<0.0001\right)$. As in AcbSh slices, antagonist treatment alone was not sufficient to produce significant increases in phosphorylation of GluR1 $\operatorname{pSer}^{845}$ (Fig. 3B).

The pharmacological studies were complemented by analysis of GluR1 pSer $^{845}$ in genetic models of altered $\mathrm{MCH}$ levels. MCH-OE (Shimada et al., 1998) animals have increased food intake and body weight, while MCH-KO (Ludwig et al., 2001) mice are lean and eat less food. MCH-OE animals showed reduced basal GluR1 pSer ${ }^{845}$ (Fig. $\left.3 C\right)\left(t_{(1,21)}=3.022\right.$, $p<0.01)$, whereas MCH-KO mice showed increased GluR1 pSer $^{845}$ (Fig. 3D) $\left(t_{(1,15)}=2.527, p<0.05\right)$. The observed changes were found to be specific to phosphorylation of GluR1, as no differences were seen in total GluR1 levels (supplemental Fig. S2 B, C, available at www.jneurosci.org as supplemental material). Detection of these predicted changes in vivo, as well as in genetic models, confirms the persistence and consistency of the biochemical findings.

\section{$\mathrm{MCH}$ reduces cell surface GluR1 expression and mEPSC amplitude}

The AcbSh is a key feeding center that integrates neural signals from many brain regions (Kelley, 2004). Given its effects on GluR1 phosphorylation in the AcbSh, MCHR1 signaling would likely modulate the influence of excitatory, glutamatergic inputs. PKA activity and phosphorylation of Ser ${ }^{845}$ on GluR1 subunit is known to enhance AMPA receptor (AMPAR) cell-surface expression and influence synaptic plasticity in many brain regions, including the nucleus accumbens, prefrontal cortex, and hip-
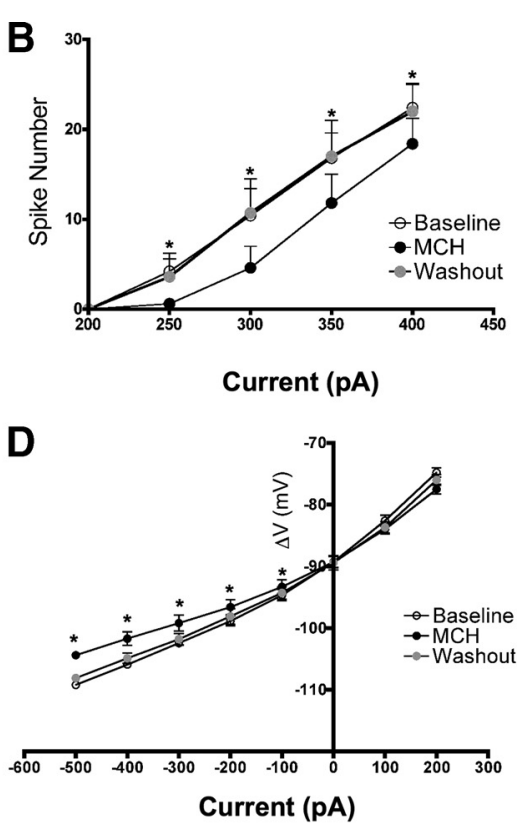

$\mathbf{F}$

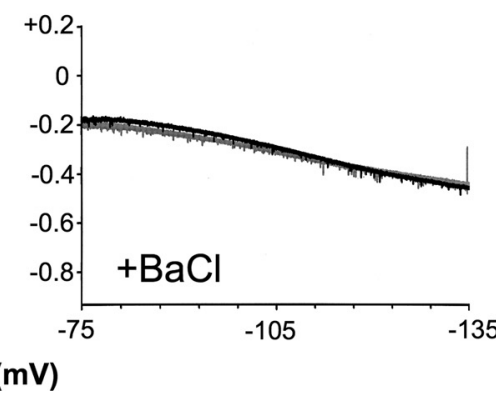

Voltage $(\mathrm{mV})$

Figure 5. MCH reduces action potential firing in AcbSh MSNs through modulation of $\mathrm{K}^{+}$currents. $\boldsymbol{A}$, Traces for positive current

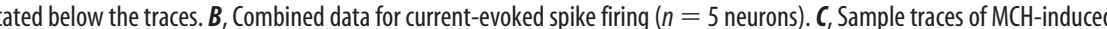

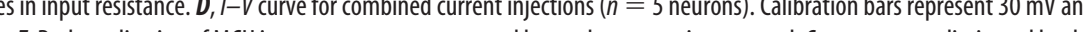
data from cells treated with $\mathrm{MCH}(n=17)$ or $\mathrm{BaCl}(n=4) .{ }^{*} p<0.05$. Error bars indicate +SEM.

pocampus (Greengard et al., 1991; Wang et al., 1991; Keller et al., 1992; Blackstone et al., 1994; Rosenmund et al., 1994; Takahashi et al., 2003; Sun et al., 2005; Oh et al., 2006). In contrast, reduced phosphorylation at $\operatorname{Ser}^{845}$ reduces surface expression and functionality of GluR1-containing AMPARs (Banke et al., 2000; Lee et al., 2000; Man et al., 2007). Consistent with reduced Ser ${ }^{845}$ phosphorylation of GluR1, MCH treatment caused a significant reduction in surface levels of GluR1 relative to intracellular GluR1 (Fig. $4 A)\left(F_{(1,26)}=9.099, p<0.006\right)$. Notably, the magnitude of this reduction is comparable to the reduction of phosphorylation seen on $\operatorname{Ser}^{845}$. The surface reduction was specific to GluR1containing AMPAR, as no significant change was seen with GluR2-containing AMPARs, NR1-containing NMDARs, and TrkB, an unrelated growth factor receptor (data not shown). MCHR1 antagonist blocked the effects of $\mathrm{MCH}$ on the surface expression of GluR1 (Fig. 4A).

$\mathrm{MCH}$-mediated reduction in surface (functional) GluR1containing AMPARs would be expected to reduce mEPSCs, a measure of synaptic AMPAR activity. To explore this possibility, whole-cell patch-clamp recordings were made in the voltageclamp configuration on medium spiny neurons (MSNs) of the 

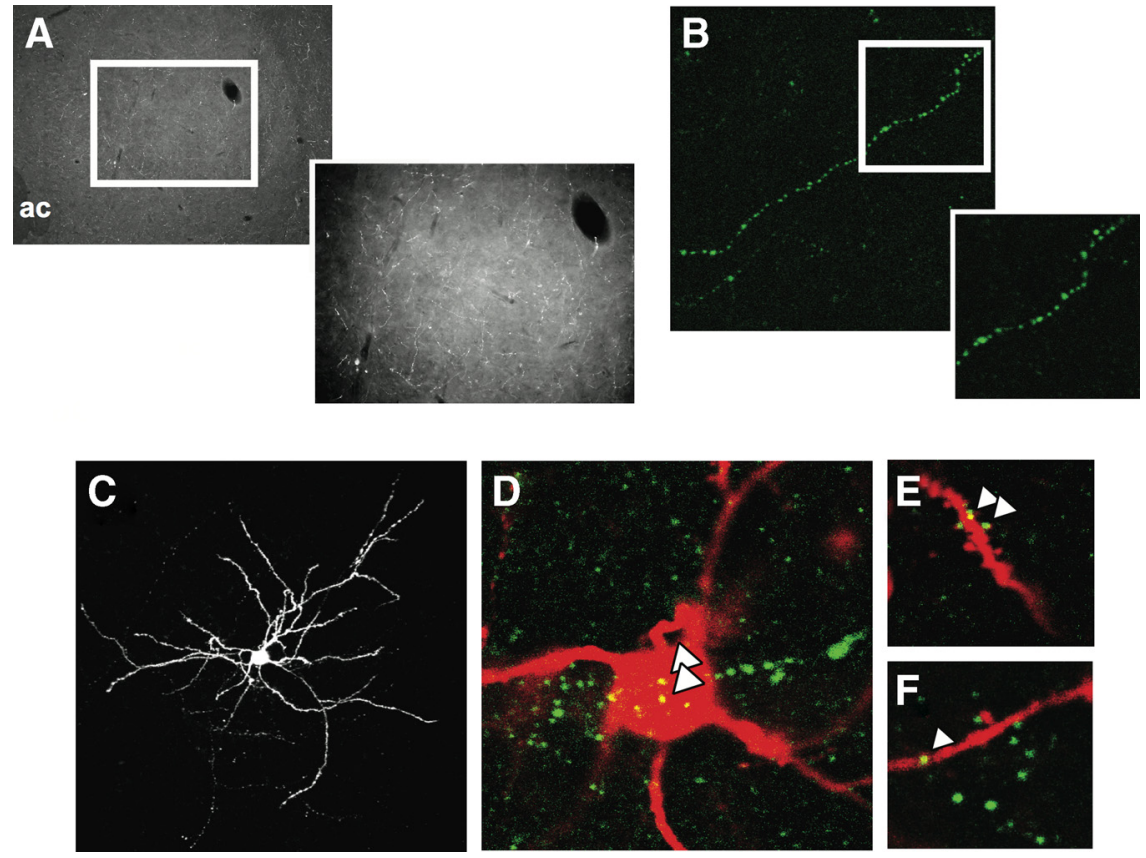

Figure 6. MCH-positive axon fibers are intimately associated with MSNs. A, A $100 \times$ image of MCH immunostaining, with $200 \times$ inset. $B, A 60 \times$ two-photon image of MCH-immunopositive varicosities (in green) in the AcbSh. $C$, MCH-responsive MSN filled with Neurobiotin (red). $\boldsymbol{D}-\boldsymbol{F}, \mathrm{MCH}$-immunopositive varicosities (green) are found within $1 \mu \mathrm{m}$ of the soma (red) $(\boldsymbol{D})$ and dendrites $(\boldsymbol{E}, \boldsymbol{F})$. White arrows indicate points of contact. ac, Anterior commissure.
$\mathrm{K}^{+}$currents. A majority of MSNs (17 of 22) responded to $\mathrm{MCH}$ with increased rectification beyond the reversal potential of $\mathrm{K}^{+}$, an effect that was blocked by 100 $\mu \mathrm{M}$ barium (Fig. $5 E, F$ ). Consistent with the current-clamp data, mean reversal potential $\left(E_{\text {rev }}\right)$ for $\mathrm{MCH}$-responsive cells was $90.66 \pm 1.68$, the $E_{\text {rev }}$ of $\mathrm{K}^{+}$under these experimental conditions. This increased rectification was not blocked by TTX, indicating the effect of $\mathrm{MCH}$ on $\mathrm{K}^{+}$ currents is cell autonomous (data not shown). Together, these data indicate that $\mathrm{MCH}$ reduces action potential firing of MSNs through modulation of $\mathrm{K}^{+}$ conductance.

During recordings, neurons were filled with Neurobiotin and slices were processed for $\mathrm{MCH}$ immunostaining to visualize $\mathrm{MCH}$ axons originating from the hypothalamus. Using laser scanning twophoton imaging, $\mathrm{MCH}$-positive varicosities were found in close proximity $(<1$ $\mu \mathrm{m})$ to soma, dendritic branches, and dendritic spines, suggesting that $\mathrm{MCH}$ axons are well positioned to influence MSN function (Fig. 6).
AcbSh. Consistent with the observed biochemical effects of $\mathrm{MCH}$, a significant reduction in mEPSC amplitude was observed upon $\mathrm{MCH}$ application in most MSNs (Fig. 4, compare $C$ to $B$; data summarized in $D)\left(t_{(1,114)}=6.799, p<0.0001\right)$. No significant change in mEPSC frequency was observed, suggesting that the observed effects are postsynaptic (Fig. $4 E$ ). Perfusion of slices with $1 \mu \mathrm{M}$ CNQX completely blocked mEPSCs, confirming that these events are AMPAR mediated (data not shown). These data demonstrate a neuropeptide-mediated reduction in basal surface levels of GluR1-containing AMPARs, and suggest one mechanism by which MCH could modulate excitability of the MSNs.

\section{MCH modulates MSN excitability through increased $\mathrm{K}^{+}$ channel rectification}

While modulation of AMPA receptors can reduce synaptic excitability, other GPCR-mediated mechanisms can reduce the propensity of neurons to fire action potentials. To evaluate whether $\mathrm{MCH}$ can modulate the passive membrane properties of MSNs, positive current steps were applied in current-clamp mode before and during $\mathrm{MCH}$ treatment. The frequency of evoked action potentials in MSNs increased in a current-dependent fashion (Fig. $5 A, B)\left(F_{(4,16)}=41.67, p<0.001\right)$. MCH application reduced the frequency of action potentials $\left(F_{(1,4)}=21.147, p<\right.$ 0.01 ) at all current steps within the first few minutes of $\mathrm{MCH}$ bath application, indicating a role for $\mathrm{MCH}$ in suppressing the excitability of these neurons. Furthermore, MCH significantly decreased input resistance, resulting in a flattened I/V curve (Fig. $5 C, D)\left(F_{(1,4)}=27.68, p<0.006\right)$. The observed reversal potential $\left(E_{\text {rev }}\right)$ was near $-90 \mathrm{mV}$, consistent with $E_{\text {rev }}$ of $\mathrm{K}^{+}$. In nonneuronal expression systems and neuronal cell culture experiments, $\mathrm{MCH}$ has been shown to activate inhibitory $\mathrm{K}^{+}$currents (for review, see Gao, 2009). Moreover, membrane excitability in MSNs is known to be mediated in large part by $\mathrm{K}^{+}$channels (Dong et al., 2006). To better characterize this response, a ramping protocol was used to determine voltage-dependent changes in

\section{$\mathrm{MCH}$ reduces cell firing in AcbSh in vivo}

The current data demonstrate that $\mathrm{MCH}$ modulates biochemical measures of neuronal activity in AcbSh slices and in vivo and influences synaptic and cellular excitability of MSNs. To evaluate the effects of $\mathrm{MCH}$ on neuronal activity in awake, freely moving animals, neuronal data were collected during direct infusions of aCSF and $\mathrm{MCH}$ with microwire recording electrodes implanted in the AcbSh. We found that $\mathrm{MCH}$ significantly decreased neuronal activity for $30 \mathrm{~min}$ after infusion compared to aCSF (Fig. 7) $\left(t_{(1,11)}=3.63, p<0.0041\right)$. No significant difference was observed $40 \mathrm{~min}$ after infusions $\left(t_{(1,11)}=1.23, p<0.24\right)$. These data are consistent with the recordings in AcbSh slice preparations, and suggest that $\mathrm{MCH}$ decreases activity of neurons in vivo. At the conclusion of these experiments, FCM, a $\mathrm{GABA}_{\mathrm{A}}$ receptor agonist that inactivates neurons and can be readily visualized (Narayanan et al., 2006; Allen et al., 2008), was infused into cannulae while neuronal data were collected. The reduction in firing caused by this independent compound confirmed that local drug infusions can affect nearby neurons (supplemental Fig. S4, available at www.jneurosci.org as supplemental material).

\section{Discussion}

A number of brain regions have been studied for their role in food intake, and there is a need to understand how they integrate to drive this behavior. The present data establish that $\mathrm{MCH}$ acts via its receptor to influence the activity of AcbSh MSNs. Specifically, MCHR1 acts via $G_{i / o}$ coupling to influence PKA-sensitive phosphoproteins in MSNs. Analysis of neuronal activity revealed two downstream processes by which $\mathrm{MCH}$ reduces the excitability of MSNs in the AcbSh: a reduction mEPSC amplitude and a decrease in action potential firing as mediated by increased membrane $\mathrm{K}^{+}$conductance. These signaling mechanisms reduce neuronal excitability, a result confirmed in vivo. Together these data describe biochemical and cellular mechanisms mediating the interface between the hypothalamus and mesolimbic system 
A

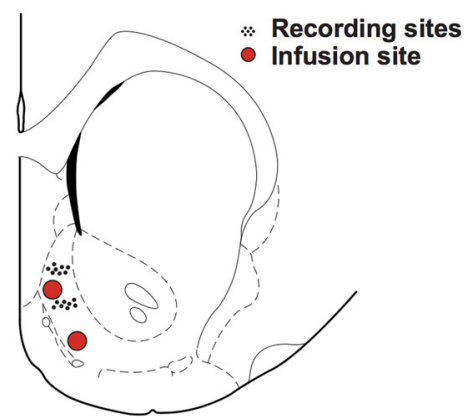

B

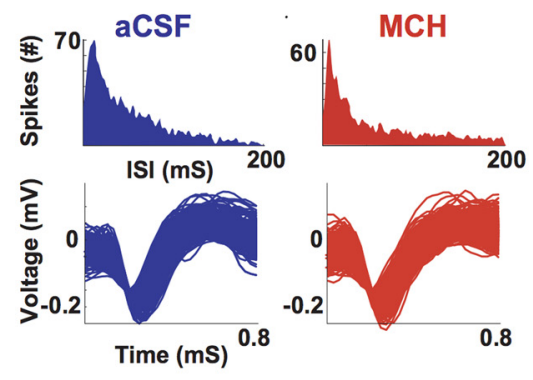

C
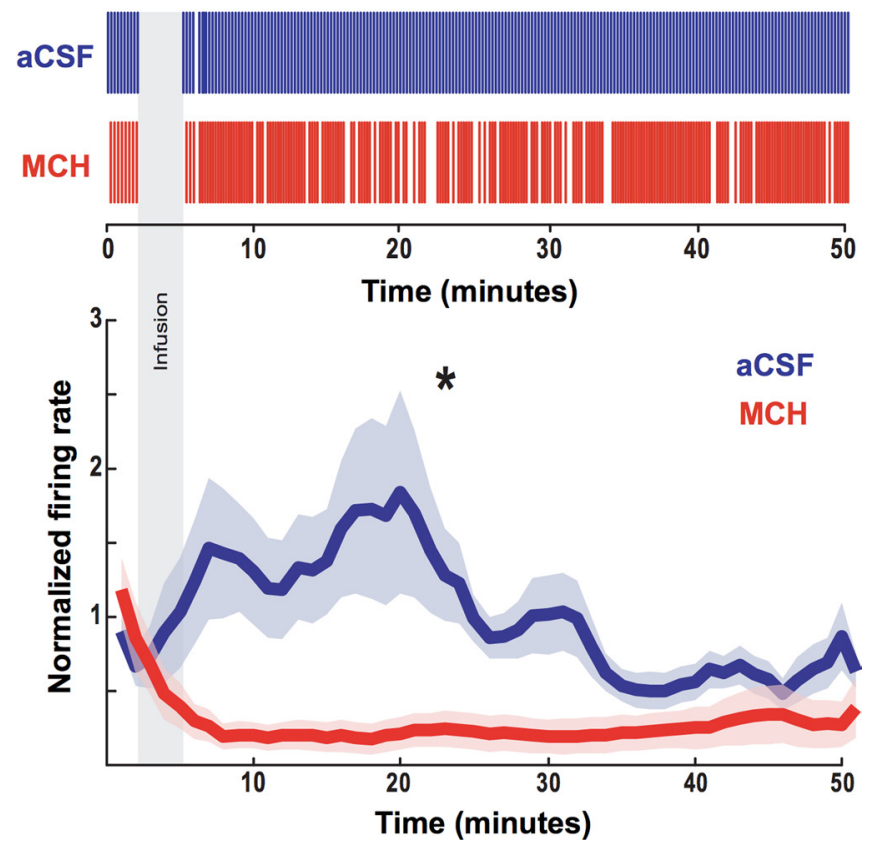

Figure 7. MCH decreases neuronal activity in vivo. $\boldsymbol{A}$, Location of electrodes (black circle) and cannula (red circle) projected on an atlas section from Paxinos and Watson (1982). $\boldsymbol{B}$, Interspikeinterval histograms and waveforms from a single unit in aCSF infusion sessions (left) and the same neuron in MCH infusion sessions (right). $\boldsymbol{C}$, Raster plot representing firing rate for a single unit (top) during aCSF and MCH treatment sessions. Gray box represents time of infusion. Below is the average neuronal activity for MCH sessions $\left(n=7\right.$ neurons) and aCSF ( $n=8$ neurons). ${ }^{*} p<0.01$.

and support an cellular excitability hypothesis of AcbShmediated food intake behavior (Kelley, 2004).

The observed effects of MCH on GluR1 levels and mEPSCs are consistent with functions seen in many brain regions. A reduction in GluR 1 pSer ${ }^{845}$ is associated with reduced surface receptor levels and conductance of GluR1-containing AMPARs (Banke et al., 2000; Lee et al., 2000; Man et al., 2007). Moreover, patchclamp recordings in the nucleus accumbens show that reduced surface expression and AMPAR activity occur in response to lowfrequency stimulation-induced long-term depression (Thomas et al., 2001; Brebner et al., 2005). Recent studies suggest that GluR1 pSer ${ }^{845}$ prevents lysosomal degradation of GluR1 (Kessels et al., 2009), although no total protein differences were observed in the present experiments.

MSNs in the basal ganglia express a wide array of voltagegated and "leak" $\mathrm{K}^{+}$channels critical for membrane homeostasis (Mermelstein et al., 1998; Baranauskas et al., 1999; HernándezPineda et al., 1999). Studies in striatum and nucleus accumbens demonstrate that these channels are responsible for the hyperpolarized resting potential and high firing threshold of MSNs (Nisenbaum et al., 1994, 1996; Nisenbaum and Wilson, 1995; Gabel and Nisenbaum, 1998; Belleau and Warren, 2000; Shen et al., 2004). Moreover, several G-protein-gated $\mathrm{K}^{+}$channels (GIRKs) are expressed in the nucleus accumbens, and are known to be regulated through $\mathrm{G}_{\mathrm{q}}$ and $\mathrm{G}_{\mathrm{i} / \mathrm{o}}$ activity (Kurachi and Ishii, 2004). Specifically, both $\mathrm{G}_{\mathrm{q}} \alpha$ and $\mathrm{G}_{\mathrm{i}} \beta \gamma$ proteins are known to modulate GIRKs directly - the former inhibit and the latter activate these channels (Lei et al., 2003). The current data demonstrate a robust $\mathrm{MCH}$-mediated increase in basal $\mathrm{K}^{+}$conductance and reduced action potential firing, which is consistent with $G_{i / o}$ coupling in the AcbSh.

Given the high expression of MCHR1 in the AcbSh, a major target of the mesolimbic dopamine system, a number of studies have focused on $\mathrm{MCH}$-dopamine interactions. Biochemical, amperometric, and behavioral studies in the nucleus accumbens of MCH- and MCHR1-knock-out mice show that the absence of $\mathrm{MCH}$-mediated signaling allows for increased dopamine release and increased dopamine receptor levels (Smith et al., 2005; Tyhon et al., 2006; Pissios et al., 2008; Tyhon et al., 2008). These data explain enhanced behavioral and biochemical responses to drugs of abuse in the absence of $\mathrm{MCH}$ signaling, although one study contrasts with these findings and the data presented here (Chung et al., 2009). Chung et al. (2009) show that MCH can synergize with dopamine signaling to promote enhanced responses to drugs of abuse and increases in action potential firing in MSNs of the AcbSh. Unlike in the present work, basal or dopamine-agonist-independent changes in action potential firing were not reported and signaling mechanisms were not explored. Moreover, as discussed below, inhibition of MSN activity by $\mathrm{MCH}$ is consistent with pharmacological and cellular data connecting AcbSh inhibition with food intake. Since most studies find that MCH or MCHR1 mutant animals display reduced feeding or body weight gain, yet increased responses to psychostimulants, a distinction emerges between behavioral responses to food versus drugs of abuse. MCH-dopamine interactions likely underlie these behavioral effects, and the current data suggest a direct mechanism by which MCH could modulate feeding, and possibly responses to drugs of abuse, via changes in excitability of MSNs.

The striatum/nucleus accumbens is composed 90-95\% MSNs, which are mainly characterized as D1R- or D2Rexpressing neurons (Chang et al., 1982; Chang and Kitai, 1985). We have reported that MCHR1 message is found in both D1R(Dyn) and D2R- (Enk) expressing neurons in the AcbSh (Georgescu et al., 2005), suggesting that MCHR1 signaling would occur in all MSNs. Moreover, in our in vivo recording experiment, all recorded neurons were inhibited by $\mathrm{MCH}$, consistent with the inhibitory response seen in many cells in our slice studies. However, this does not mean that both types of neurons are inhibited in vivo, and additional studies with reporter mice are needed to 
evaluate direct $\mathrm{MCH}$ inhibition of both D1R- and D2Rexpressing neurons.

Physiological evidence suggests that reduced nucleus accumbens activity is important for motivated behaviors for "natural" rewards. Experiments looking at responses to reinforcers such as sucrose, food, or water have demonstrated a prominent reduction in cell firing in a majority of nucleus accumbens neurons during both learned and spontaneous motivated behavior for sucrose (Nicola et al., 2004; Taha and Fields, 2006). Cellular inhibition of nucleus accumbens neurons is also important for the reinforcing effects of brain stimulation reward, also a motivated behavior (Cheer et al., 2005). Reductions in neuronal excitability were also found during self-administration paradigms for drugs of abuse (Chang et al., 1994; Peoples et al., 2007; Carlezon and Thomas, 2009), and manipulations that reduce MSN excitability in the AcbSh increase the locomotor responses to cocaine (Dong et al., 2006). A recent study demonstrates that high conductance AMPARs (GluR2-lacking AMPARs) are upregulated in response to drug withdrawal, or "craving" (Conrad et al., 2008). Much work has been dedicated to connecting the mechanisms of "natural" reward to the reinforcing effects of drugs of abuse, and changes in MSN neuronal excitability in the AcbSh appear to be associated with both.

The ability of MCH to reduce MSN excitability in the AcbSh implicates this hypothalamic neuropeptide in a general model of nucleus accumbens-mediated feeding behavior. Previous studies have demonstrated that AcbSh infusions of AMPAR antagonists or $\mathrm{GABA}_{\mathrm{A}}$ receptor agonists, both of which reduce neuronal activity, lead to robust increases in baseline feeding behavior (Maldonado-Irizarry et al., 1995; Stratford and Kelley, 1997; Stratford et al., 1998). In contrast, AMPA infusion reduces consumption of food in deprived animals (Maldonado-Irizarry et al., 1995; Stratford et al., 1998). In light of these studies, the present data suggest that $\mathrm{MCH}$ stimulates feeding through a reduction in overall excitability of the AcbSh.

Considering the role of the $\mathrm{LH}$ as an integrator of metabolic signals and the function of the AcbSh in controlling motivational or incentive-related aspects of food seeking, it is not surprising that the LH should influence the activity of the AcbSh. MCH serves as a molecular candidate for mediating this circuit. There is evidence that $\mathrm{MCH}$ cells respond to metabolic signals within the hypothalamus: behavioral manipulations such as food restriction and deprivation that decrease hypothalamic leptin signaling cause increases in MCH mRNA expression (Kokkotou et al., 2001) and specific activation of pathways in $\mathrm{MCH}$ neurons (Georgescu et al., 2005). In contrast, leptin administration directly into the brain promotes a decrease in $\mathrm{MCH}$ mRNA expression (Kokkotou et al., 2001). Increased activity of MCH neurons may increase peptide release in the AcbSh, where glutamatergic inputs converge from many brain areas, including cortical regions (Mogenson et al., 1980). Through activation of MCHR1, the influence of cortical excitatory inputs would be blunted due to reduced AMPAR activity, and action potential firing of MSNs would decrease through GIRK channel activation. We propose that $\mathrm{MCH}$ mediates the convergence of metabolic and cortical signals in the AcbSh in this manner. Interestingly, the effects of changes in MSN excitability are likely to influence food intake through a neural connection back to the LH. The AcbShmediated feeding effects of AMPAR antagonists and GABA receptor agonists require LH activation (Stratford and Kelley, 1999). In this context, MCH could thus modulate the output of the AcbSh via direct mechanisms studied here, as well as indirectly via an LH-AcbSh-LH circuit that influences orexin neuron activity (Zheng et al., 2003). Other targets of MSN projection neurons would also be relieved of inhibition, including the medial ventral pallidum and the ventral tegmental area (Kelley, 2004).

In sum, data presented here suggest a model where previously demonstrated MCH-mediated effects on consummatory behaviors occur through reduction in MSN excitability in the AcbSh. This work provides a mechanism for this behavioral effect, and describes how an endogenous hypothalamic-limbic neuromodulatory system can influence feeding behavior.

\section{References}

Allen TA, Narayanan NS, Kholodar-Smith DB, Zhao Y, Laubach M, Brown $\mathrm{TH}$ (2008) Imaging the spread of reversible brain inactivations using fluorescent muscimol. J Neurosci Methods 171:30-38.

Bächner D, Kreienkamp H, Weise C, Buck F, Richter D (1999) Identification of melanin concentrating hormone $(\mathrm{MCH})$ as the natural ligand for the orphan somatostatin-like receptor 1 (SLC-1). FEBS Lett 457:522-524.

Banke TG, Bowie D, Lee H, Huganir RL, Schousboe A, Traynelis SF (2000) Control of GluR1 AMPA receptor function by cAMP-dependent protein kinase. J Neurosci 20:89-102.

Baranauskas G, Tkatch T, Surmeier DJ (1999) Delayed rectifier currents in rat globus pallidus neurons are attributable to $\mathrm{Kv} 2.1$ and $\mathrm{Kv} 3.1 / 3.2 \mathrm{~K}^{+}$ channels. J Neurosci 19:6394-6404.

Bednarek MA, Hreniuk DL, Tan C, Palyha OC, MacNeil DJ, Van der Ploeg LH, Howard AD, Feighner SD (2002) Synthesis and biological evaluation in vitro of selective, high affinity peptide antagonists of human melanin-concentrating hormone action at human melanin-concentrating hormone receptor 1. Biochemistry 41:6383-6390.

Belleau ML, Warren RA (2000) Postnatal development of electrophysiological properties of nucleus accumbens neurons. J Neurophysiol 84:2204-2216.

Berton O, Nestler EJ (2006) New approaches to antidepressant drug discovery: beyond monoamines. Nat Rev Neurosci 7:137-151.

Bittencourt JC, Presse F, Arias C, Peto C, Vaughan J, Nahon JL, Vale W, Sawchenko PE (1992) The melanin-concentrating hormone system of the rat brain: an immuno- and hybridization histochemical characterization. J Comp Neurol 319:218-245.

Blackstone C, Murphy TH, Moss SJ, Baraban JM, Huganir RL (1994) Cyclic AMP and synaptic activity-dependent phosphorylation of AMPApreferring glutamate receptors. J Neurosci 14:7585-7593.

Boudreau AC, Wolf ME (2005) Behavioral sensitization to cocaine is associated with increased AMPA receptor surface expression in the nucleus accumbens. J Neurosci 25:9144-9151.

Brebner K, Wong TP, Liu L, Liu Y, Campsall P, Gray S, Phelps L, Phillips AG, Wang YT (2005) Nucleus accumbens long-term depression and the expression of behavioral sensitization. Science 310:1340-1343.

Cardinal RN, Parkinson JA, Hall J, Everitt BJ (2002) Emotion and motivation: the role of the amygdala, ventral striatum, and prefrontal cortex. Neurosci Biobehav Rev 26:321-352.

Carlezon WA Jr, Thomas MJ (2009) Biological substrates of reward and aversion: a nucleus accumbens activity hypothesis. Neuropharmacology 56 [Suppl 1]:122-132.

Chang HT, Kitai ST (1985) Projection neurons of the nucleus accumbens: an intracellular labeling study. Brain Res 347:112-116.

Chang HT, Wilson CJ, Kitai ST (1982) A Golgi study of rat neostriatal neurons: light microscopic analysis. J Comp Neurol 208:107-126.

Chang JY, Sawyer SF, Lee RS, Woodward DJ (1994) Electrophysiological and pharmacological evidence for the role of the nucleus accumbens in cocaine self-administration in freely moving rats. J Neurosci 14:1224-1244.

Cheer JF, Heien ML, Garris PA, Carelli RM, Wightman RM (2005) Simultaneous dopamine and single-unit recordings reveal accumbens GABAergic responses: implications for intracranial self-stimulation. Proc Natl Acad Sci U S A 102:19150-19155.

Chung S, Hopf FW, Nagasaki H, Li CY, Belluzzi JD, Bonci A, Civelli O (2009) The melanin-concentrating hormone system modulates cocaine reward. Proc Natl Acad Sci U S A 106:6772-6777.

Conrad KL, Tseng KY, Uejima JL, Reimers JM, Heng LJ, Shaham Y, Marinelli M, Wolf ME (2008) Formation of accumbens GluR2-lacking AMPA receptors mediates incubation of cocaine craving. Nature 454:118-121. 
Della-Zuana O, Presse F, Ortola C, Duhault J, Nahon JL, Levens N (2002) Acute and chronic administration of melanin-concentrating hormone enhances food intake and body weight in Wistar and Sprague-Dawley rats. Int J Obes Relat Metab Disord 26:1289-1295.

Dong Y, Green T, Saal D, Marie H, Neve R, Nestler EJ, Malenka RC (2006) CREB modulates excitability of nucleus accumbens neurons. Nat Neurosci 9:475-477.

Gabel LA, Nisenbaum ES (1998) Biophysical characterization and functional consequences of a slowly inactivating potassium current in neostriatal neurons. J Neurophysiol 79:1989-2002.

Gao XB (2009) Electrophysiological effects of MCH on neurons in the hypothalamus. Peptides 30:2025-2030.

Gao XB, van den Pol AN (2001) Melanin concentrating hormone depresses synaptic activity of glutamate and GABA neurons from rat lateral hypothalamus. J Physiol 533:237-252.

Georgescu D, Sears RM, Hommel JD, Barrot M, Bolaños CA, Marsh DJ, Bednarek MA, Bibb JA, Maratos-Flier E, Nestler EJ, DiLeone RJ (2005) The hypothalamic neuropeptide melanin-concentrating hormone acts in the nucleus accumbens to modulate feeding behavior and forced-swim performance. J Neurosci 25:2933-2940.

Gomori A, Ishihara A, Ito M, Mashiko S, Matsushita H, Yumoto M, Ito M, Tanaka T, Tokita S, Moriya M, Iwaasa H, Kanatani A (2003) Chronic intracerebroventricular infusion of $\mathrm{MCH}$ causes obesity in mice. Melanin-concentrating hormone. Am J Physiol Endocrinol Metab 284:E583-E588.

Greengard P, Jen J, Nairn AC, Stevens CF (1991) Enhancement of the glutamate response by cAMP-dependent protein kinase in hippocampal neurons. Science 253:1135-1138.

Hawes BE, Kil E, Green B, O’Neill K, Fried S, Graziano MP (2000) The melanin-concentrating hormone receptor couples to multiple $\mathrm{G}$ proteins to activate diverse intracellular signaling pathways. Endocrinology 141:4524-4532.

Hernández-Pineda R, Chow A, Amarillo Y, Moreno H, Saganich M, VegaSaenz de Miera EC, Hernández-Cruz A, Rudy B (1999) Kv3.1-Kv3.2 channels underlie a high-voltage-activating component of the delayed rectifier $\mathrm{K}+$ current in projecting neurons from the globus pallidus. J Neurophysiol 82:1512-1528.

Hervieu GJ, Cluderay JE, Harrison D, Meakin J, Maycox P, Nasir S, Leslie RA (2000) The distribution of the mRNA and protein products of the melanin-concentrating hormone $(\mathrm{MCH})$ receptor gene, slc-1, in the central nervous system of the rat. Eur J Neurosci 12:1194-1216.

Ito M, Gomori A, Ishihara A, Oda Z, Mashiko S, Matsushita H, Yumoto M, Ito M, Sano H, Tokita S, Moriya M, Iwaasa H, Kanatani A (2003) Characterization of MCH-mediated obesity in mice. Am J Physiol Endocrinol Metab 284:E940-E945.

Keller BU, Hollmann M, Heinemann S, Konnerth A (1992) Calcium influx through subunits GluR1/GluR3 of kainate/AMPA receptor channels is regulated by cAMP dependent protein kinase. EMBO J 11:891-896.

Kelley AE (2004) Ventral striatal control of appetitive motivation: role in ingestive behavior and reward-related learning. Neurosci Biobehav Rev 27:765-776.

Kelley AE, Berridge KC (2002) The neuroscience of natural rewards: relevance to addictive drugs. J Neurosci 22:3306-3311.

Kessels HW, Kopec CD, Klein ME, Malinow R (2009) Roles of stargazin and phosphorylation in the control of AMPA receptor subcellular distribution. Nat Neurosci 12:888-896.

Kokkotou EG, Tritos NA, Mastaitis JW, Slieker L, Maratos-Flier E (2001) Melanin-concentrating hormone receptor is a target of leptin action in the mouse brain. Endocrinology 142:680-686.

Kurachi Y, Ishii M (2004) Cell signal control of the G protein-gated potassium channel and its subcellular localization. J Physiol 554:285-294.

Lee HK, Barbarosie M, Kameyama K, Bear MF, Huganir RL (2000) Regulation of distinct AMPA receptor phosphorylation sites during bidirectional synaptic plasticity. Nature 405:955-959.

Lei Q, Jones MB, Talley EM, Garrison JC, Bayliss DA (2003) Molecular mechanisms mediating inhibition of $G$ protein-coupled inwardlyrectifying $\mathrm{K}+$ channels. Mol Cells 15:1-9.

Liu RJ, Lambe EK, Aghajanian GK (2005) Somatodendritic autoreceptor regulation of serotonergic neurons: dependence on L-tryptophan and tryptophan hydroxylase-activating kinases. Eur J Neurosci 21:945-958.

Ludwig DS, Tritos NA, Mastaitis JW, Kulkarni R, Kokkotou E, Elmquist J, Lowell B, Flier JS, Maratos-Flier E (2001) Melanin-concentrating hor- mone overexpression in transgenic mice leads to obesity and insulin resistance. J Clin Invest 107:379-386.

Maldonado-Irizarry CS, Swanson CJ, Kelley AE (1995) Glutamate receptors in the nucleus accumbens shell control feeding behavior via the lateral hypothalamus. J Neurosci 15:6779-6788.

Man HY, Sekine-Aizawa Y, Huganir RL (2007) Regulation of \{alpha\}amino-3-hydroxy-5-methyl-4-isoxazolepropionic acid receptor trafficking through PKA phosphorylation of the Glu receptor 1 subunit. Proc Natl Acad Sci U S A 104:3579-3584.

Mashiko S, Ishihara A, Gomori A, Moriya R, Ito M, Iwaasa H, Matsuda M, Feng Y, Shen Z, Marsh DJ, Bednarek MA, MacNeil DJ, Kanatani A (2005) Antiobesity effect of a melanin-concentrating hormone 1 receptor antagonist in diet-induced obese mice. Endocrinology 146:3080-3086.

Mermelstein PG, Song WJ, Tkatch T, Yan Z, Surmeier DJ (1998) Inwardly rectifying potassium (IRK) currents are correlated with IRK subunit expression in rat nucleus accumbens medium spiny neurons. J Neurosci 18:6650-6661.

Mogenson GJ, Jones DL, Yim CY (1980) From motivation to action: functional interface between the limbic system and the motor system. Prog Neurobiol 14:69-97.

Narayanan NS, Horst NK, Laubach M (2006) Reversible inactivations of rat medial prefrontal cortex impair the ability to wait for a stimulus. Neuroscience 139:865-876.

Nicola SM, Yun IA, Wakabayashi KT, Fields HL (2004) Firing of nucleus accumbens neurons during the consummatory phase of a discriminative stimulus task depends on previous reward predictive cues. J Neurophysiol 91:1866-1882.

Nisenbaum ES, Wilson CJ (1995) Potassium currents responsible for inward and outward rectification in rat neostriatal spiny projection neurons. J Neurosci 15:4449-4463.

Nisenbaum ES, Xu ZC, Wilson CJ (1994) Contribution of a slowly inactivating potassium current to the transition to firing of neostriatal spiny projection neurons. J Neurophysiol 71:1174-1189.

Nisenbaum ES, Wilson CJ, Foehring RC, Surmeier DJ (1996) Isolation and characterization of a persistent potassium current in neostriatal neurons. J Neurophysiol 76:1180-1194.

Oh MC, Derkach VA, Guire ES, Soderling TR (2006) Extrasynaptic membrane trafficking regulated by GluR1 serine 845 phosphorylation primes AMPA receptors for long-term potentiation. J Biol Chem 281:752-758.

Paxinos G, Watson C (1982) The rat brain in stereotaxic coordinates. New York: Academic Press.

Peoples LL, Kravitz AV, Guillem K (2007) The role of accumbal hypoactivity in cocaine addiction. ScientificWorldJournal 7:22-45.

Pissios P, Trombly DJ, Tzameli I, Maratos-Flier E (2003) Melaninconcentrating hormone receptor 1 activates extracellular signal-regulated kinase and synergizes with $\mathrm{G}(\mathrm{s})$-coupled pathways. Endocrinology 144:3514-3523.

Pissios P, Frank L, Kennedy AR, Porter DR, Marino FE, Liu FF, Pothos EN, Maratos-Flier E (2008) Dysregulation of the mesolimbic dopamine system and reward in $\mathrm{MCH}-/-$ mice. Biol Psychiatry 64:184-191.

Qu D, Ludwig DS, Gammeltoft S, Piper M, Pelleymounter MA, Cullen MJ, Mathes WF, Przypek R, Kanarek R, Maratos-Flier E (1996) A role for melanin-concentrating hormone in the central regulation of feeding behaviour. Nature 380:243-247.

Reynolds SM, Berridge KC (2001) Fear and feeding in the nucleus accumbens shell: rostrocaudal segregation of GABA-elicited defensive behavior versus eating behavior. J Neurosci 21:3261-3270.

Robbins TW, Everitt BJ (1996) Neurobehavioural mechanisms of reward and motivation. Curr Opin Neurobiol 6:228-236.

Rosenmund C, Carr DW, Bergeson SE, Nilaver G, Scott JD, Westbrook GL (1994) Anchoring of protein kinase A is required for modulation of AMPA/kainate receptors on hippocampal neurons. Nature 368:853-856.

Rossi M, Choi SJ, O’Shea D, Miyoshi T, Ghatei MA, Bloom SR (1997) Melanin-concentrating hormone acutely stimulates feeding, but chronic administration has no effect on body weight. Endocrinology 138:351-355.

Saito Y, Cheng M, Leslie FM, Civelli O (2001) Expression of the melaninconcentrating hormone $(\mathrm{MCH})$ receptor mRNA in the rat brain. J Comp Neurol 435:26-40.

Shearman LP, Camacho RE, Sloan Stribling D, Zhou D, Bednarek MA, Hreniuk DL, Feighner SD, Tan CP, Howard AD, Van der Ploeg LH, MacIntyre DE, Hickey GJ, Strack AM (2003) Chronic MCH-1 receptor 
modulation alters appetite, body weight and adiposity in rats. Eur J Pharmacol 475:37-47.

Shen W, Hernandez-Lopez S, Tkatch T, Held JE, Surmeier DJ (2004) Kv1.2containing $\mathrm{K}+$ channels regulate subthreshold excitability of striatal medium spiny neurons. J Neurophysiol 91:1337-1349.

Shimada M, Tritos NA, Lowell BB, Flier JS, Maratos-Flier E (1998) Mice lacking melanin-concentrating hormone are hypophagic and lean. Nature 396:670-674.

Skofitsch G, Jacobowitz DM, Zamir N (1985) Immunohistochemical localization of a melanin concentrating hormone-like peptide in the rat brain. Brain Res Bull 15:635-649.

Smith DG, Tzavara ET, Shaw J, Luecke S, Wade M, Davis R, Salhoff C, Nomikos GG, Gehlert DR (2005) Mesolimbic dopamine super-sensitivity in melanin-concentrating hormone-1 receptor-deficient mice. J Neurosci 25:914-922.

Snyder GL, Galdi S, Fienberg AA, Allen P, Nairn AC, Greengard P (2003) Regulation of AMPA receptor dephosphorylation by glutamate receptor agonists. Neuropharmacology 45:703-713.

Stratford TR, Kelley AE (1997) GABA in the nucleus accumbens shell participates in the central regulation of feeding behavior. J Neurosci 17:4434-4440.

Stratford TR, Kelley AE (1999) Evidence of a functional relationship between the nucleus accumbens shell and lateral hypothalamus subserving the control of feeding behavior. J Neurosci 19:11040-11048.

Stratford TR, Swanson CJ, Kelley A (1998) Specific changes in food intake elicited by blockade or activation of glutamate receptors in the nucleus accumbens shell. Behav Brain Res 93:43-50.

Sun X, Zhao Y, Wolf ME (2005) Dopamine receptor stimulation modulates
AMPA receptor synaptic insertion in prefrontal cortex neurons. J Neurosci 25:7342-7351.

Taha SA, Fields HL (2006) Inhibitions of nucleus accumbens neurons encode a gating signal for reward-directed behavior. J Neurosci 26:217-222.

Takahashi T, Svoboda K, Malinow R (2003) Experience strengthening transmission by driving AMPA receptors into synapses. Science 299: $1585-1588$.

Thomas MJ, Beurrier C, Bonci A, Malenka RC (2001) Long-term depression in the nucleus accumbens: a neural correlate of behavioral sensitization to cocaine. Nat Neurosci 4:1217-1223.

Tyhon A, Adamantidis A, Foidart A, Grisar T, Lakaye B, Tirelli E (2006) Mice lacking the melanin-concentrating hormone receptor-1 exhibit an atypical psychomotor susceptibility to cocaine and no conditioned cocaine response. Behav Brain Res 173:94-103.

Tyhon A, Lakaye B, Grisar T, Tirelli E (2008) Deletion of MelaninConcentrating Hormone Receptor-1 gene accentuates D-amphetamineinduced psychomotor activation but neither the subsequent development of sensitization nor the expression of conditioned activity in mice. Pharmacol Biochem Behav 88:446-455.

Vaughan JM, Fischer WH, Hoeger C, Rivier J, Vale W (1989) Characterization of melanin-concentrating hormone from rat hypothalamus. Endocrinology 125:1660-1665.

Wang LY, Salter MW, MacDonald JF (1991) Regulation of kainate receptors by cAMP-dependent protein kinase and phosphatases. Science 253:11321135.

Zheng H, Corkern M, Stoyanova I, Patterson LM, Tian R, Berthoud HR (2003) Peptides that regulate food intake: appetite-inducing accumbens manipulation activates hypothalamic orexin neurons and inhibits POMC neurons. Am J Physiol Regul Integr Comp Physiol 284:R1436-R1444. 